\title{
Saints and Celebrities
}

\author{
Tine Van Osselaer
}

In Autumn 1871, the French doctor Antoine Imbert-Gourbeyre embarked on a journey to visit Palma Matarrelli (1825-1888). In a description of this visit, he insisted that he had seen her forehead bleed spontaneously, and that he had witnessed two miraculous communions and the divine fire twice. According to Imbert-Gourbeyre, none of these phenomena could be simulated, it was all supernatural in origin and he was willing to testify about what he had seen. ${ }^{1} \mathrm{He}$ was not alone in his enthusiasm as Matarrelli was famous throughout Italy and abroad, and many thought of her as divinely "blessed."

Four years later, in 1875, Imbert-Gourbeyre's enthusiasm faced the cold Vatican reality when the verdict of the book censors left no doubt about the fate of Les stigmatisées, volume II: Palma d'Oria, his hagiography of Matarrelli. "[He must] behave as a good Catholic, and make sure that his work no longer circulates and does not appear in a second edition." With this condemnation, the book fared worse than the first volume of Les stigmatisées, which had focused on the Belgian stigmatic, Louise Lateau (1850-1883). According to the censors, the first volume did "not present anything dangerous, or immoral, only extravagant and partially admissible things [...]." Although the Vatican generally adopted a critical stance towards stigmatics, the censorship of the French doctor's book was exceptional, as only a few books on stigmatics caught the Vatican's attention. ${ }^{3}$ However, Imbert-Gourbeyre's enthusiasm for Louise

1 Imbert-Gourbeyre, Les Stigmatisées: Palma d'Oria, 3, 28, 62. Nevertheless, he did seem to believe that in these matters the final decision was up to the Vatican, as he quoted Palma on how she disapproved of the experiments performed on Louise Lateau by "common individuals" ("simples particuliers") as only Rome had the power to judge in these matters.

2 "L'opera nulla presenta di pericoloso, o d'immorale, ma cose stravaganti ed in parte non ammissibili." "La mente è che venga egli informato segretamente sui fatti di Palma d'Oria. Egli deve essere istruito in proposito, e lo ecciti a procurare come buon cattolico, che non sia diffusa la di lui opera e che non ne faccia una nuova edizione." Archives of the Congregation of the Doctrine of Faith (ACDF), Censurae librorum (C.L.)1875, Oria 1875, f. 186 and 187 r. Full title of the second volume published in 1873 in Paris, Les stigmatisées, vol. II: Palma d'Oria, examen de la thèse rationaliste, liste historique des stigmatisés. We thank Leonardo Rossi for this reference.

3 See also ACDF, C.L., 1875, Boëns Hubert, Louise Lateau ou les mystères de Bois d'Haine dévoilés. 
Lateau and Palma Matarrelli was certainly not unprecedented. In the following chapters we aim to demonstrate that the popularity of the stigmatics had much to do with the fact that while they might not have reflected the Vatican's concept of a saint, for their lay contemporaries they did accord with their ideas of both a saint and a religious celebrity. In order to understand these dynamics, this chapter reflects on: (1) the concepts of celebrity and sanctity, (2) the specificity of the period that we are studying when addressing these concepts, (3) the compatibility of the two and (4) finally, the practices and narratives that produced them.

\section{Saints in the Spotlight}

Thanks to the daily press, the young girl was soon well known to the masses of the public and the name of Louise Lateau travelled from mouth to mouth. Here and there one could read in some "trivial facts" that compact crowds gathered from all sides, from Belgium and abroad, to attend, on Friday, the scenes that took place in the cottage in Bois d'Haine. ${ }^{4}$

There can be no doubt that Louise Lateau's fame extended far beyond the boundaries of her small village. From the first reports of her stigmata (1868) until her death in 1883 at the telling age of 33 , she continued to attract attention (from the press and visitors). In June 1874, L'Écho du Parlement, a Brussels liberal newspaper, commented on her popularity in Germany and mockingly called her a "new celebrity," who would make a "tour of the Catholic world." 5 This notion of "celebrity" is what interests us here. Until now, religion has gained little attention in celebrity studies. ${ }^{6}$ Those religious figures who have been singled out, Padre Pio, Mother Theresa and Thérèse of Lisieux, ${ }^{7}$ have explicitly been linked to the mass media of the twentieth century. However, as the above quotation shows, some stigmatics were perceived as "celebrities" as

4 "Grâce à la presse quotidienne, la jeune fille fut bientôt connue de la masse du public et le nom de Louise Lateau courait de bouche en bouche. Çà et là on pouvait lire dans quelques 'faits divers' que des foules compactes accouraient de tous côtés, de la Belgique et de l'étranger, pour assister, le vendredi, aux scènes qui se passaient dans la chaumière de Bois d'Haine," Anonymous, Louise Lateau devant l'Académie Royale de Médecine de Belgique (1876), 4-5.

5 “... tour du monde catholique," V.G., "Une nouvelle célébrité," L'Écho du Parlement (24 June 1874), 3 .

6 See also our themed issue on Catholic celebrities of Journal of Religious History, 42.4 (December 2018).

7 Krass, "Stigmata und yellow press;" Margry, "Merchandising and sanctity;" Alpion, "Media and celebrity culture;" Deboick, "Céline Martin's images." 
early as the nineteenth century; ${ }^{8}$ people were as interested in buying images of the stigmatics, ${ }^{9}$ learning about their lives and eager to obtain their autographs. ${ }^{10}$

A caveat needs to be added here, however, as we must be careful not to assume that twentieth-century celebrities such as Mother Theresa were the same as Louise Lateau. The concept of "celebrity" is historically contingent, and as Lenard Berlanstein, summarizes: "Rather than positing a constant meaning, it would be better to approach celebrity culture as something that has been continuously reinvented and that appealed to different groups - including elite ones - as the culture changed."11 While the term "celebrity" is about 16o years old, "the phenomenon itself - the combination of renown, visibility, and fascination with a personality - is much older." ${ }^{\prime 2}$ As we will see in Chapter 5 , the type of celebrity associated with some of our stigmatics was like that of people whose fame spread through the modern media and became marketable - they were "carefully constructed religious commodities"13 whose acts, lives and image drew the public's interest. ${ }^{14}$ Mediatized fame has a different logic to it than, for example, the word of mouth promotion of the fama sanctitatis of a local "holy" person to whom people turned for help.

We address stigmatics as celebrities in the era of the emerging mass media and mass production in Europe. In this period, the number of celebrities was increasing and the fame of the stigmatic could be cultivated through such sources as newspaper articles and cheap booklets. However, as noted, depending on your definition of celebrity, one can detect religious celebrities in other periods. Aviad Kleinberg, for example, suggests that celebrity and celebrity culture do not have to be related to marketing and mass media. Focusing on medieval popular saints, he noted that mass enthusiasm, admiration and the object of the admiration turning themselves into what the public wanted them

8 See e.g. Louis Jourdan and Taxtile Delord, Les célébrités du jour (The celebrities of the day), a work published in 186o-1861, they equated celebrity with public leaders or heroes, e.g. Garibaldi, but also included Pope Pius Ix. Reference in Berlanstein, "Historicizing," 72.

9 See e.g., Muhs, "Die Stigmata," 25.

10 Priesching, Maria von Mörl, 401.

11 Berlanstein, "Historicizing," 66-67.

12 Berlanstein, "Historicizing," 67: "Leon Braudy posits that the conditions for a 'democratization' of fame proliferated in Western Europe by the early eighteenth century as print media developed and as people of high birth lost their monopoly over distinction." Nevertheless, even before the arrival of mass media (after 1850), the number of celebrities was on the rise due to the expansion of newspaper readership, lithography and other media, and "a general democratization of culture and politics in the post-French revolutionary era," Berenson and Giloi, "Introduction," 2.

13 Deboick, "Céline Martin's images," 377.

14 Morgan, "Celebrity," 98. 
to be can also be detected in previous eras. ${ }^{15}$ The parallels between the fame of saints and celebrities have been noted for more recent eras as well. Scholars such as Chris Rojek and Peter Jan Margry have pointed to similarities between modern celebrity culture and the cult of saints ${ }^{16}$ and referred to cultic celebrity followers, who collected new "relics" (the celebrity photo) and went on new "pilgrimages" (celebrity graves and houses). ${ }^{17}$

The modern stigmatics were regarded as celebrities and saints by their contemporaries. Neither of these labels had a fixed meaning and what exactly a saint was, depended to no small extent on the context. In 1916, the German promotors of a Belgian stigmatic, Rosalie Put (1868-1919, stigmata 189o), addressed this issue, stating that: "If we call Rosalie privatim a blessed or holy person, we have the right to do this. No one can forbid us to do that. [...] We allow everyone the freedom to judge this, as their conscience tells them is right." They explicitly defended their right to call her a saintly person and, in their opinion, their judgement was no different to that of other Catholic authors who wrote about the lives of exceptional people, considered them saints, or mentioned miracles that had occurred through their mediation after death - and sometimes even during their lifetime. They wrote in these hagiographic terms, despite the fact that "the Church had very often not yet officially declared them 'saints', yes not even 'blessed' and had not officially examined the reported miracles." In other words, Rosalie Put's supporters only claimed "human credibility" ("menschliche Glaubwürdigkeit") for the phenomena and events they described. ${ }^{18}$ Two elements are of importance here: firstly, the stigmatic's supporters believed her to be a holy person; and secondly, they were well aware that whoever they might call saintly or blessed, might not necessarily be regarded as such by the Catholic Church. ${ }^{19}$ This latter element is of central importance in our analysis of the popularity of "stigmatics." We will address the Vatican's response to some of the stigmatics in detail in Chapter 7 , what interests us here is the reputation of holiness as Rosalie Put's supporters understood this. The focus is on the unofficial level: people who were perceived as saints while they were still alive - the "living saints" 20 - and those

15 Kleinberg, "Are saints," passim.

16 Rojek, Celebrity; Margry, "The Pilgrimage."

17 Howells, "Heroes;" Schmitt, Les saints; Margry, "The Pilgrimage."

18 A. Mons (= Theodor Timming), Eine Gottbegnadete, 27.

19 On this issue, see the PhD project of Leonardo Rossi, L. Rossi, "Embodied, feigned, canonized holiness. Stigmatics in late modern Italy (c. 1800-1950)," Ruusbroec Lecture, 14 June 2019.

$20 \quad$ These were "individuals considered saints by their contemporaries," Kleinberg, Prophets, 1 , who attracted a certain veneration, while the ecclesiastical authorities had not yet made a pronouncement on their case, Frijhoff, "Bedevaart," 196. 
whose reputation for holiness continued after their death without the official sanctioning of the Church - folk saints. ${ }^{21}$ As we will see, we can find "stigmatics" in both groups of unofficial saints. ${ }^{22}$

Thus, rather than focus on stigmatics that have been canonized (and thus can be considered "official" saints), the book addresses sainthood from a broader, lay perspective by focusing primarily on stigmatics during their lifetime. ${ }^{23}$ "Living saints," had been part of the mystical tradition since medieval times. They were often lay women - not seldom tertiaries who lived what was known as a "mixed life" - who had attracted the attention of their contemporaries for their supernatural charisms, especially prophecies and miracles. The religious parallels of the lay "living saints" were the holy nuns ("monaca santa"). Through their heroic virtues and extraordinary prodigies, they deserved the title of blessed or saint despite being unrecognized. Their reputation for holiness often remained within a convent's wall, but sometimes their fame also spread beyond the cloister. This religious type of stigmatic probably reached a peak in the seventeenth and eighteenth centuries, but there were also several cases reported in the contemporary age, especially in Spain and Italy.

The type of sanctity that the modern stigmatics represented was more the saint as a "revelatory token" than the saint as a model of Christian life. ${ }^{24}$ Often the stigmata formed the initial point of attraction, ${ }^{25}$ while other qualities (such as the capacity to heal) were added to the stigmatic's reputation in a later phase. The people who visited the stigmatics interpreted them to be powerful intermediaries between earthly and divine being: they asked the stigmatics to pray with them for their cause (e.g. conversion) and believed in a "shared pain" model (the stigmatic suffers as a substitute for the sick/afflicted). ${ }^{26}$ After the death of these women, the cults sometimes lingered on, even without the support of the ecclesiastical authorities. This is illustrated, for example, in the following statement from a devotee of Anna Katherina Emmerick around 1892 (several decades after the death of Emmerick in 1824): "I could never venerate A.C., even if she is not canonized by the Church, as anything else than a saint, I already held several novenas to her with the greatest confidence and I have

21 "folk saints ... informal additions to the Catholic canon," Graziano, Folk Saints, 29.

22 The supporters of Rosalie Put, for example, referred to the book of Kempf, Die Heiligkeit der Kirche im 19. Jahrhundert, therein we can find reference to, among others, Anna Katharina Emmerick, Gemma Galgani, Elisabetta Canori-Mora and Anna Maria Taigi. Although they featured in a book about sanctity, none of them were official saints at the time of publication (in 1913).

23 Klaniczay, "Louise Lateau," 285; Frijhoff, Heiligen, 19-20; Ciappara, "Simulated sanctity."

24 Walsh, "Pope John Paul II," 435; Van de Port, "Not made by human hand." On this aspect, see Chapter 3.

25 Seeger, Resl von Konnersreuth, 91.

26 Margry, "The passion," 162; Seeger, Resl von Konnersreuth, 103. On this topic, see Chapter 3. 
been heard several times. ${ }^{27}$ Ex-votos on the graves of some of stigmatics, such as Clara Jung and Louise Lateau, show how some were still perceived as mediators after their deaths. Of these stigmatized "folk saints," some were called on for help for specific crises (e.g. financial issues - Clara Jung), while others had a more general profile. ${ }^{28}$

What is perceived as saintly by some is not necessarily regarded as such by others. The "saintliness" of the stigmatics was a communal, often renegotiated, construction, being the product of an interaction of the "saintly" person with his/her community, created through discourse and religious practices (e.g. rituals of veneration, but also the stigmatic's public solo performance of Christ's passion). ${ }^{29}$ This symbiotic relationship between the stigmatic and the community resulted in local variations, with different communities and different times calling for different types of saints (living or dead). ${ }^{30}$ What was perceived as sanctity in one country was not necessarily so in another. In 1931, a frustrated devotee of Anna Katherina Emmerick wrote to a fellow supporter that the Germans were too critical in these matters: "France would have put A.C.E., the great social benefactor, on altars long ago" ("Frankreich hätte A.K.E. die grosse soziale Wohltäterin längst auf den Altären")..1

Anna Katherina Emmerick is one of the few stigmatics of our period who gained official recognition from the Vatican: she was beatified in 2004. In many cases, the reputation for holiness (as well as that of false holiness) did not rely on proof of the extraordinary abilities of the mystic, but rather on the perception (positive or negative) of the community and other contemporaries. This term, therefore, has an essentially local and geographically determined value,

27 "Ich selbst könnte A.C., auch wenn sie von der Kirche nicht heilig gesprochen würde, nicht anders als eine Heilige verehren, ich habe schon manche neuntägige Andachte zu ihr und zwar mit großem Vertrauen gehalten und bin auch verschiedentlich erhört worden." Bistumarchiv Münster (BAM), Sammlung Anna-Katharina-Emmerick und Louise Hensel (Emmerick/Hensel), 40. Stimmen über die Verehrung aus dem Volke, Gesammelt von P. Th. Wegener 1877-1883 (Stimmen). Abschrift aus Nr. 41; 81 S. (geheftet) und 8 Einzelblätter mit Konzepten, Namenslisten und Abschriften, alte Sign. IV.6, 19. Witwe Arkten in Rödder (pp. 25-27), Bauerschaft von Dülmen, 1820 geb. erzählt als sie 72 Jahre alt war.

28 This also holds true for official saints such as Maria Francesca of the Five Wounds. She lived before the era under discussion (she died in 1791), but she was beatified in 1843 and became a saint in 1867. Childless couples travelled to her in Naples and asked for her help (see: https://www.cbsnews.com/news/does-miracle-chair-help-fertility/).

29 Wiethaus, "Bloody bodies," 195; Scheer, "Das Medium," 172.

3o Kleinberg, Prophets, 1 and 4.

31 BSB, Nachlass Lama, Friedrich von (1876-1944), Ana 445, file 2: letter from Essen-Ruhr, 6/5/31, Maria Vildhaut. 
but this does not exclude the spread of the fama sanctitatis on different levels (regional, national, international). As we will see Chapter 7 , Rome was rather reluctant to recognize stigmatics as saints and, if they did, their wounds were either minimized or ignored.

\section{The Scale of Fame: Transnational and Comparative Approach}

Ideas on sanctity and on celebrity are historically contingent. ${ }^{32}$ Who or what they were or could be depended on the historical and geographical contexts and, in the modern era, the latter could be vast and multiple. Two important shifts took place in the nineteenth century that were not entirely unconnected and influenced the reception and construction of stigmatics as saints and/or celebrities: (1) the scale of their fame increased in the media due to the improvement and low cost of mass publication; and (2) the internationalization and centralization of Catholicism/Catholic devotional culture.

The nineteenth century was an era in which mass production of devotional objects and a growing Catholic internationalism enhanced the uniformization and internationalization of Catholic devotional culture. ${ }^{33}$ Catholic pilgrims travelled to internationally attractive religious sites such as Lourdes and read books about mystics from other countries translated into their own language. This international and transnational perspective has primarily been adopted in research on popularized cults, such as Sacred Heart devotion or Marian or other apparition sites. ${ }^{34}$ Unauthorized cults have fared less well in this respect even though, as we will show throughout the book, they also benefitted from the increasing media possibilities and transnational networks.

We do not want to suggest that the development of an unauthorized cult, or foreign visitors to such a site were the standard scenario in the life stories of stigmatics. The impact of the stigmatic varied from one case to another. In some cases, their fame did not travel beyond the local level. ${ }^{35}$ In other cases, such as Louise Lateau and Therese Neumann, the news of their stigmatization spread worldwide. Given this reception beyond the local community, it is important to reflect on the broadening of the scale and/or speed of reception, as it also had an impact on the response to stigmatics and their devotion and

32 Similarly, as Nicole Priesching, "Mystikerinnen," 79, has noted, mystics are defined by the array of experiences and interpretations offered by their society, and differ accordingly.

33 Viaene, "International history."

34 See e.g. on Lourdes, Kotulla, "Nach Lourdes!"

35 See e.g. the case of Marie Cilissen (1883, Zichen) and Marianne Tekotte (1844, Althrede). 
promotion. In his work on celebrities, Simon Morgan has warned historians that this:

[...] flow of goods, images, writings and celebrities themselves between countries and even continents means that historians must consider the international dimension of fame, and the complexities of examining the reception of particular individuals in different national contexts. ${ }^{36}$

Similarly, Jo Littler noted in her work on celebrity and the transnational that "[c]elebrities can, of course, be glocalized and consumed differently in different places, their meaning shifting alongside their geographical context." She thereby referred to, among others, the work of Rana Gopal on Mother Theresa (of Calcutta), noting that she was never the type of celebrity in India that she was in Europe and the United States, where she functioned as a neo-colonial figure of compassion and care from the West. ${ }^{37}$

However, the difference lay not only in the perception of the religious celebrity, but also in the production of the celebrity persona (what a celebrity is/ can be). ${ }^{38}$ Not all stigmatics developed into international celebrities, but in some cases - particularly those who recurred in the different lexica and lists (e.g. Louise Lateau) - it safe to call them world famous. Moreover, in the case of the twentieth-century German stigmatic, Therese Neumann, it is clear that the promotors had a broad international market in mind (see e.g. La Chronique de Konnersreuth, a French translation of the German original series by Friedrich Ritter von Lama).

The transnational aspect of the enthusiasm for stigmatics has been the topic of some recent in-depth studies by Kristof Smeyers and Leonardo Rossi. They studied the response of English Catholics to Maria von Mörl and Maria Domenica Lazzeri in the 1830s-1840s, and meticulously traced the networks involved, the routes that the pilgrims took and the meaning they attached to their visit. ${ }^{39}$ In addition, they also looked into the reception and impact of the idea of the stigmatics in the British Isles. ${ }^{40}$ Similarly, Tine Van Osselaer

\footnotetext{
36 Morgan, "Celebrity," 110.

37 Littler, "Celebrity," 1.

$38 \quad$ Littler, "Celebrity," 1; Berlanstein, "Historicizing," 68.

39 Leonardo Rossi and Kristof Smeyers, "Into the land of the living saints: travelling to see stigmata in Tyrol, 183os-40s," International Conference "Walking with saints: protection, devotion and civic identity," Ronse, 24-26 May 2018. Smeyers and Rossi, "Tyrolean stigmata".

40 Kristof Smeyers and Leonardo Rossi, "Tyrolean stigmatics in Britain and Ireland, 18411843," Catholic Record Society Annual Conference, Cambridge, 24 July 2017.
} 
has worked on the reception of another "canonical" stigmatic, Louise Lateau. She has shown how the Belgian stigmatic from Bois d'Haine became a symbolic figure in the culture wars in both Belgium and Germany. For the German Catholics, Louise Lateau's suffering seemed to symbolize their political struggles in the 187 os. $^{41}$ Given the worldwide fame of stigmatics such as Lateau and Lazzeri, it is not so surprising to find sources on their cases in other countries. However, we also find such foreign interest in less well-documented cases, such as those of the Belgian Rosalie Put and the German Maria Göbl (18861941, stigmata 1923).

These latter cases show how the enthusiasm that developed beyond the borders of their own diocese and country provided specific challenges for the ecclesiastical authorities during the lifetime of the stigmatic and after their death. Rosalie Put was not popular in her own region at all, but triggered a lot of interest in German Westphalia. According to her parish priest, there were several reasons for this German interest: firstly, Rosalie Put had a sister in a cloister in Fauquemont. Most of the sisters there were German and they seem to have taken responsibility for the movement. Secondly, it seems that there were several propagandists in Westphalia who directed paying or other visitors to the Belgian stigmatic. In the opinion of curé Truyens, the best thing to do was to warn the clergy in Westphalia using "one or the other organ of publicity" ("une organe quelconque de publicité"), indicating that the visits should cease, as no proof of the supernatural origin of the phenomena had been provided and, on the contrary, everything seemed to point to a purely natural disease. ${ }^{42}$

It was a rather tricky situation, as Rosalie Put's own bishop did not hold any authority over devotees of a German diocese, while the German bishops had no power over the Belgian stigmatic. The clergy of Westphalia did not really need to be warned about the dangers of this enthusiasm for the Belgian stigmatic. An initial first cry for help had reached the Bishop of Köln in 1901. While he contacted his Belgian colleague, the Bishop of Liège, there was no public statement. However, several years later, towards the end of 1909, the German complaints (this time by the Bishop of Münster) were heard in Liège. In late 1909 and early 1910, the Vicar General of Liège published a public statement in German diocesan periodicals, as well as in the popular press and the Belgian newspapers stating that, while within Rosalie Put's own community there was "no misunderstanding" that the case involved "only strange, abnormal signs of illness," "[f]rom afar, however, especially from some places in

\footnotetext{
41 Van Osselaer, "Stigmata."

42 Antwerp, Ruusbroec Institute (RI), Fonds Jan Nulens, 1.1. letter of Curé Truyens, 23 March 1908 to "Monseigneur."
} 
Germany [...] many inexperienced and credulous people are attracted." ${ }^{43}$ The publication of the letter did not have the effect that was hoped for and German Catholics continued to travel to Put's hometown in Lummen. Even after her death, her memory was kept alive through a number of sources, including the publication in German of the memoirs of Helene Hofmann, Meine Besuche bei der belgischen Stigmatisierten Rosalie Püt (My visits to the Belgian stigmatic Rosalie Put, 199o).

In summary, to control the German enthusiasm for Rosalie Put, the Belgian episcopal authorities made good use of the outreach potential of the modern media, as did Put's lay opponents. The power of the written word and the confusion that developed when a stigmatic drew attention beyond the borders of her own country, also played an important role in the post-mortem enthusiasm for the German stigmatic, Anna Maria Göbl. During her lifetime, Göbl's own bishop (of Trier) warned "with emphasis" in April 1927, in a public letter read out loud in churches and published in church periodicals, "not to visit the mentioned sick person or to create propaganda for her."44

While the visits continued and a booklet on Göbl was published in 1928 (Georg Priller, Anna Maria Goebel. Die stigmatisierte von Bickendorf, Eifel), the diocese of Trier did not get involved in the matter again. That is, until a priest from Eupen (in German-speaking Belgium), decided to publish a hagiography of her, and asked and received the imprimatur of the diocese of Liège (Belgium). ${ }^{45}$ What followed was an intense correspondence between the Belgian and the German episcopal authorities in Trier, who could not understand how their Belgian colleagues had let this book through. In May 1957, the Vicar General published a statement in the church periodical of the diocese claiming that the ways in which the author represented the phenomena was not in line with the outcome of the examination by the episcopal commission. He advised that further circulation of the booklet was forbidden

43 " [...] dass nur eigenartige, abnorme Krankheitserscheinungen zu bestimmten Zeiten sich einstellen [...] sodass in der nächsten Umgebung kein Missverständnis mehr besteht und nur noch die Neugierde einige Anziehungskraft ausübt. Aus der Ferne aber, speziell aus einigen Orten Deutschlands, werden infolge einer nicht zu billigenden Mache immer noch zahlreiche unerfahrene und leichtgläubige Leute herangezogen," "Zu dem Fall der im Pfarrdorfe Lummen wohnhaften Rosalia Pütt" published, among others, in Kirchlicher Anzeiger für Diözese Cöln, December 18, 1909, Echo der Gegenwart (January 8, 1910), Niederrheinische Volkszeitung and Het nieuws van den dag, January 8, 1910.

44 “[...] warnt auf das eindringlichste die Katholiken, die genannte Kranke zu besuchen oder gar Propaganda für sie zu machen.” Bistumsarchiv Trier (вАт), Causa Göbel-Faber, Bickendorf, BIII.12, $10 \mathrm{Bd}$. 3f, "Übernatürliche Erscheinungen an einer Kranken in Bickendorf" (10/4/1927).

Ernst, Goebel Anna Maria (1956). 
and that the faithful who already had a copy in their possession needed to be warned. ${ }^{46}$

Transnational enthusiasm such as this seems to have flourished in a sort of grey zone of episcopal control. In order to temper the fervour, the bishops made use of the modern media, such as the press, whose outreach potential they were well aware of. If we want to adequately capture the enthusiasm for stigmatics we will thus have to address different levels of their reception and construction as saints and celebrities. They were as meaningful for devotees visiting their local "living saint" as they were to Catholic politicians looking for a symbolic figure who could appeal to many.

\section{$3 \quad$ Religious Celebrities}

Stigmatics such as Louise Lateau were not the first religious celebrities featuring in modern media. Scholars including Hans De Valk and Vincent Viaene, ${ }^{47}$ who have studied the popes of the nineteenth and twentieth centuries, have shown how the Holy See consciously engaged in creating an emotionally laden public image of the Pope. The loss of political power - through Italian unification and the siege and loss of the Papal States - inspired an intense campaign to win the hearts of Catholics and thus also their loyalty for the "pope-martyr." All means were mobilized as the Pope reached the hearts of the faithful through press sermons, pastoral letters, novenas and mass manifestations. Mass-produced signed images of the Pope circulated world-wide and enabled the faithful to feel a personal connection. ${ }^{48}$ The recent book, Popestar. Der Papst und die Medien, explores this development and discusses the papal presence in the press, both as an object (he became one of the most photographed and publicly discussed figures) and as a subject, with his own publicity machine, including papal photographers, press speakers and newspapers. ${ }^{49}$

Similarly, as Claude Langlois and Ruth Harris (among others) have shown in their studies of Bernadette Soubirous, the Church used the means of modern industrial society (press and photography) to promote models of sanctity

46 BAT, Abt. R-BGV 9 Nr.229, Imprimatur 1957, "Warnung: Goebel Anna Maria, die stigmatisierte Opferseele von Bickendorf (Eifel)," Kirchliches Verordnungsblatt für die Diözese Gurk 15/5/1957, 45 .

47 De Valk, "De cultus van de paus;" Viaene "Het Italiaanse Risorgimento."

48 Viaene, "Het Italiaanse Risorgimento," 264. See also Rusconi, Santo Padre, and Rusconi, "Santo Padre."

49 Klimczak and Petersen (eds.), Popestar. On the media popes in the twentieth and twentyfirst centuries, see De Valk, "De cultus van de paus," 335. 
to a Catholic mass audience..$^{50}$ The promotional campaign of the visionary of Lourdes, who was the first saint to be photographed, had already begun during her lifetime. Postcards showed reenactments of the Marian apparitions with Bernadette Soubirous in the traditional dress of the Pyrenean region. This choice of wardrobe aimed to evoke her humble and rural background, seen as further confirmation of the authenticity of her apparitions. Portraying her modest background also made her accessible to the Catholic devotees, since she looked both "exceptional and ordinary." ${ }^{11}$ As we will discuss in more detail in the following chapters, this dynamic also seems to be at work in the representation of the stigmatics. For our discussion here, it is important to note that a humble background could be put to strategic use: celebrity came within reach of both the small and the mighty.

The ordinary lay faithful also made it into the spotlight. While often more short lived than the celebrity status of the Pope or a saint-to-be, temporary fame was within reach of the lucky few who were miraculously cured by the Virgin. In her work on Lourdes as a commercially attractive pilgrimage site, Suzanne Kaufman has addressed this production and marketing of miraculées as religious celebrities. ${ }^{52}$ There was much to gain: for the Church these cures could function as proof of God's continuing intervention on earth, while also becoming a major selling point for the pilgrimage site. "The process of transforming the otherwise-ordinary miraculée into a public figure", as Kaufman notes, "was absolutely crucial to making Lourdes one of the most popular and visited pilgrimage shrines by the beginning of the twentieth century."53 The guidebooks, postcards, articles (e.g. in the weekly newsletter, Le Pèlerin) and overviews, such as Dr Boissarie's Les grandes guérisons de Lourdes (1900), showed how unexceptional women could become objects of the miraculous, touched by the divine. Three reflections within Kaufman's discussion of the celebrity of the miraculées should be kept in mind when studying the celebrity of the stigmatics.

Firstly, referring to the mass pilgrimage and commercialized media, she notes that while the celebratory practices might have been "more extensive than earlier forms of sacred celebrity," they were also more fleeting, with most miraculées only enjoying a short moment of fame and glory. ${ }^{54}$ While news of their cure radiated beyond the pilgrimage site (through commercialized

$50 \quad$ Langlois, "Photographier," 263; Harris, Lourdes, 145, 16. See also Taylor, "Images."

$5^{1} \quad$ Kaufman, "Les Miraculées," 519.

$5^{2}$ Kaufman, Consuming visions, 148-161.

53 Kaufman, "Les Miraculées," 519.

54 Kaufman, “Les Miraculées," 519. 
media), as well as the miraculée's own town or village, and reached a national or even transnational level, the attention span was limited to "the duration of a given week's headline story in the religious press." ${ }^{25}$

Secondly, the miraculée emerged as a new kind of celebrity, someone who was worthy of attention "not because of anything that she actively achieved but rather for the extraordinary grace that she received."56 This allowed her to continue to be perceived as a modest person during her rise to national or international fame. Moreover, her name might easily be replaced by that of another miraculée, she was "a fetishised commodity - a reproducible and disposable public figure." ${ }^{57}$ The type of fame they gained, as Suzanne Kaufman nuances, was essentially different from that "of other nineteenth-century female notables. They did not look or act, for example, like the celebrated actresses of the Paris theatrical stage. Nor did they enjoy the sacred authority or popular recognition garnered by female saints or visionaries of the day."58 Nevertheless, in her public visibility, gained through press coverage, postcards and the crowds she attracted, the miraculée was similar to these modern commercialized celebrities (such as the female journalist or the Parisian actress). ${ }^{59}$ This was "no small achievement in late nineteenth-century French society, where non-elite women still enjoyed few opportunities for recognition and self-expression in the public sphere." 60

Finally, Kaufman shows how many of these miraculées actively contributed to the construction of their public image. In their testimonies concerning their cure, they presented themselves as modern martyrs and heroines of their own stories, who had kept faith although modern science had given up on them. ${ }^{61}$ In their stories, pain could be redemptive and lead to God.

As the above examples show, a saintly reputation was not necessarily at odds with mass communication and a growing consumer culture. ${ }^{62}$ The Church, clergy and lay faithful used modern means to fight aspects of modernity that they believed to be in conflict with Catholicism. Nevertheless, "such marriage

55 Kaufman, "Les Miraculées," 543.

56 Kaufman, “Les Miraculées," 534.

57 Kaufman, "Les Miraculées," 543.

58 Kaufman, “Les Miraculées," 536.

59 Kaufman, Consuming visions, 161.

6o Kaufman, Consuming visions, 154.

61 Kaufman, Consuming visions, 137, 141, 147.

62 See e.g. the work of Sofie Lachapelle on the Guide national et catholique du voyageur en France. She shows how some of the miraculées were actually included in the Catholic guidebooks published by the Assumptionist order at the turn of the twentieth century, Lachapelle, "Touring a Once Pious Nation." 
of piety and commerce was not without its tension or its detractors, coming from both secular and religious corners." 63

We must keep these reflections on modern religious celebrities in mind when discussing the celebrity status of the modern stigmatics. Some of them knew only temporary success on the local, national or even international levels, while others remained famous throughout their lifetime and beyond. Three aspects should be highlighted: (1) the fame and media attention paid to celebrity stigmatics had an impact on the representation of others; (2) some stigmatics actively engaged in creating their public image, while others merely accepted or even avoided public attention; and (3) the public image of those stigmatics who remained famous throughout a longer period could change over time.

In the first instance, among the stigmatics who became and remained international celebrities during their lifetime, the Belgian Louise Lateau and the German Therese Neumann stand out. In both cases, we find indications that their names in fact became synonymous with the "stigmatic" as a type. Publications with titles such as, "A New Therese Neumann" or "A Male Therese Neumann," not only suggest that the readers were very familiar with her case and recognized her name, but also that they knew what features someone such as Therese Neumann would be likely to display. ${ }^{64}$ In 1875 , an article appeared in a liberal weekly journal of the Ypres region in Belgium, discussing "a new Louise Lateau." Describing a new stigmatic in Bohemia, the author noted: "As you can see, a second Louise Lateau. We do not believe that it will end here. The branch of industry is good. It is still in its creation phase, and there is no doubt that what is happening in Bohemia will happen elsewhere as well. The only thing that needs to be feared is that the competition might become a little too great; if that should happen, and it is highly probable, perhaps the eyes of the good souls might open." ${ }^{\prime 65}$

For others, these famous cases were also an occasion to discuss precedents in the past. This was the case for the booklet, Anna Katharina Emmerich, Maria von Mörl und Domenika Lazzaris. Drei von Meisterhand entworfene Lebens- und

63 Lachapelle, “Touring a Once Pious Nation," 42.

64 "Eene nieuwe Louise Lateau," De Toekomst. Gazette van 't arrondissement Ijperen, 9/o5/1875, 1; Ritter von Lama, "Zweite Therese von Konneresreuth," 191-194; “Een mannelijke Therese Neumann," De Schelde, 23/o1/1928, p.1.

65 "Gelijk men ziet, eene tweede Louise Lateau. Dat het daarbij zal blijven, gelooven wij niet. De nijverheidstak is goed. Hij is nog maar in zijn ontstaan, en 't kan niet missen, of wat in Bohemen geschiedt, zal eerlang nog elders geschieden. Het eenigste wat te vreezen is, is dat de concurrentie wat groot zoude kunnen worden. Moest dat gebeuren, en 't is zeer waarschijnlijk, dan zouden de oogen der goede zielen wel eens kunnen opengaan." "Eene nieuwe Louise Lateau," De Toekomst. Gazette van 't arrondissement Ijperen, 9/o5/1875, 1. 
Leidensbilder, published by "ein Curatpriester" in 1874 . The book opened with the message that since Rohling's book on Louise Lateau was receiving so much attention, ${ }^{66}$ it was a good moment to point out that she was not a unique case.

It is important to note that these expectations about their physical appearance also seem to have influenced the ways in which new cases were described. Let us return for one moment to Elisabeth Flesch, the German case with which we opened the book. In the cartoon and the article published in Kladderadatsch, she was explicitly compared to Louise Lateau. Interestingly, studying Flesch's case more closely, it becomes clear that her corporeal phenomena were not really similar to those of Lateau. While the Belgian stigmatic bore the visible wounds of Christ on her hands and feet, Flesch sweat blood. ${ }^{67}$

The exemplary character seems to have worked on a more regional level as well. While Anna Katharina Emmerick had certainly not been an international media celebrity like Louise Lateau, she seems to have been well known in the region of Münster, and when a booklet on a new stigmatic from the area (in Dorsten), Theresia Winter (stigmata feast of St Francis 17 September 1844), appeared in 1846, its author compared her to Anna Katharina Emmerick. In fact, to be more precise, Father Heinrich Gossler described Theresia Winter with an image of Emmerick in mind, and he exaggerated the visibility of the wounds on her hands and feet as well as the crown of thorns, as in Winter's case they were apparently barely visible. ${ }^{68}$

Theresia Winter's case is an excellent example of the spiritual father and/or the stigmatic actively contributing to the creation of the public image, in this case by publishing a booklet on her visions and a lithograph showing the imprint of her head wounds (Fig. 5.1). ${ }^{69}$ Nevertheless, following the distinction suggested in research on the papal presence in the media, most stigmatics were objects rather than subjects of media attention. One exception is Elena Aiello (1895-1961, stigmata 1923), an Italian case that has been studied in more detail by Leonardo Rossi. While she was primarily an object of media attention in the initial years of her stigmatization, she continued to build her religious reputation (e.g. by opening an orphanage) and gradually became more media-savvy. She sent letters to

66 Rohling, Die Stigmatisierte von Bois d'Haine. See also Riko, "Louise Lateau en andere mystieken."

67 Freytag, Aberglauben, 344-351. Berlin, GStAPK, I.HA.Rep.77. Tit.5oo, nr. 44 Bd.1 die Maßnahmen gegen die durch die angebliche Wundererscheinungen eingetretenen Ruhestörungen, e.g. "Blutschwitzerin" in "Saarbrücken, 8. August," St. Johanner Zeitung, 9 August 1877 (Nr. 183).

68 Schulze, "Die angeblich stigmatisierte Theresia Winter," 153.

69 On this, see Chapter 5 . 
Mussolini and copies to the press, in which she warned him to keep Italy out of the war and submit to the Pope. ${ }^{70}$

In this matter, it is important to distinguish between two "circuits," each with their own logic. As Suzanne Kaufman noted, there is a difference between "popular culture - which comprises beliefs, practices, and objects that are locally produced and shared - and mass culture, in which producers and consumers typically are distinct and in which cultural forms reflect and construct urban social life while also being shared by large numbers of people outside of urban centres."71 The difference between the two circuits was certainly not clear-cut and there were interactions and overlap. The most telling example is the story of the Dutch stigmatic Dora Visser (1819-1876) as narrated by Peter Nissen. He notes that it was in fact the publication of her story in the local newspaper that instigated the cult of the Dutch stigmatic about a century after her death. ${ }^{72}$ The impact of the media on devotional culture should therefore not be underestimated.

Stigmatics functioned as objects of attention in both circuits, but their actions as subjects of attention, their efforts to create a public image, mostly relate to popular culture. A good example is the capuchin friar, Padre Pio, who had his own personal photographer and engaged in an extensive photoshoot shortly after he developed stigmata (in 1918). ${ }^{73}$ These photographs were used in devotional booklets and cards during his lifetime. We should be wary of presenting such active engagement - like that of the miraculées of Lourdes solely in a positive light. Attempting to enhance one's public image and the product lines associated with this, did make stigmatics vulnerable to accusations of seeking attention or even commercial interest. Neither had a good effect on the saintly image of the stigmatic. ${ }^{74}$

Finally, it is important to stress that apart from geographic variations in the public image of the stigmatic (depending on the intended 'consumer'), there were also chronological shifts in emphasis. This aspect is best explained by referring to the reception of Louise Lateau in Belgium. While she initially featured as a symbol for "all" Catholics, against the evil of "Liberalism", by the late 1870 os she had come only to represent the "ultramontane" Catholics (as

70 The letters were written in the 1940s and published in 1956 in Giornale d'Italia. L. Rossi, "Elena Aiello," in Stigmatics-database (https://mediahaven-stigmatics.uantwerpen.be/). Consulted on 5 July 2019.

71 Kaufman, "Les miraculées," 542, footnote 59.

72 Nissen, "Het zalig lijden," 105.

73 Krass, "Stigmata," 378; Krass, "Kontrollierter Gesichtsverlust," 80, see also Chapter 5.

74 See the case of Therese Neumann discussed in Chapter 5 ; see also the discussions of the photographs of Louise Lateau (Van Osselaer, "The affair"). 
opposed to "liberal Catholics") because of her explicit support for her former bishop against his "liberal" successor. ${ }^{75}$ Likewise, as we will see in Chapter 7 (on the Vatican response), the Church's post-mortem attitude to a stigmatic could be quite different from its previous stance and not seldom also comprised an image shift for the stigmatic involved. ${ }^{76}$

Such image shifts also characterize the post-mortem campaigns for beatification supported by both lay and religious devotees. In the case of Anna Katharina Emmerick, for example, there is a wonderful set of documents about celebrations on the occasion of the centenary of her death and about the popular devotion to her. They document how, in 1924, Emmerick had developed from a local saint and victim soul (atoning for people's lack of morality during the Napoleonic era), into a symbol of hope for all German Catholics after defeat in the First World War and the hyperinflation of 1923. It was that image of her that Father Hunkemöller promulgated when he toured the United States in 1924 to mobilize the German immigrants to contribute to her cause (with signatures and financial donations). ${ }^{77}$ The focus of this book, however, is primarily on the stigmatics during their lifetime.

\section{$4 \quad$ An Interactive Approach}

"Most of the visitors, especially the women, also visit the parish church, venture behind the high altar and behind a crucifix that is hanging on the wall there placed open and sealed letters, and notes on which everything imaginable is written." ${ }^{78}$ In 1927, one year after Therese Neumann's stigmata were first

75 On this matter, see Van Osselaer, "Stigmata." For a change of profile of the Spanish Sor Patrocinio, see Chapter 6. See also Van Osselaer, Rossi and Graus, "Virgin mothers;" and Frijhoff, "Témoins de l'autre," 43.

76 For changes in conceptions of official (post-mortem, Vatican-approved) sanctity, see e.g. Ciciliot, "Heritage talks," Bienfait, "Zeichen." De Palma, "Il modello," and Maclaren, "Modernity."

77 S.n., "Verehrung und Popularisierung," website Stadtarchiv Dülmen: (http://www.duel men.de/fileadmin/user_upload/duelmen.de/stadtarchiv/pr/ake/index.htm, consulted 14 January 2019). "Uns ist sie, wie es immer gewesen, unsere Heimatheilige, eine deutsche Heilige." Festgabe zur Erinnerung an den 100-jährigen Todestag der gottseligen Anna-Katharina Emmerick (9.Februar 1924), Dülmen: Laumann: 71. On the campaign that Father Francis Hunkemöller launched among German immigrants in the United States (1923-24), see Bistumarchiv Münster (BAM), Sammlung Anna-Katharina-Emmerick und Louise Hensel, 45. Kaplan Hunkemöllers Werbereise für Katharina Emmerich in Nordamerika 1923/24: Korrespondenz, Zeitungsauschnitte u.a., c. 1921-1924.

78 "Die meisten Besucher, besonders Frauen suchen auch die Pfarrkirche auf, begeben sich dort hinter das Hochaltar und stecken dort hinter ein an der Wand hängendes Kreuz 
reported, her saintly reputation was for many devotees still beyond doubt. The faithful did not just want to see the stigmatic, they called upon her for help using these small notes. Therese Neumann allegedly read them and prayed for what they wished for (e.g. healing of a family member or conversion of a son). Depictions such as these are wonderful examples of how "saintliness" is created through such practices. ${ }^{79}$ By putting these small notes behind the crucifix and putting their trust in the German stigmatic, these visitors showed that they believed in her power of intervention. The faithful thus participated in constructing the meaning of stigmatics using rituals and social interaction, and thereby referred to their own knowledge and traditions. ${ }^{80}$

Looking at these practices allows us to avoid an overly structuralist approach (the promotor's idea of the stigmatic), and address the "audiences" (their gaze and needs) and their involvement in the creation of the stigmatic (as saint and celebrity). We will study the practices that developed in reference to the stigmatics in the following chapters, and we can draw on recent anthropological research and address the sensational forms adopted. Birgit Meyer describes these as the "relatively fixed modes for invoking or organizing access to the transcendental" that are shared and transmitted and always linked up with specific historical and social contexts. ${ }^{81}$

We will address these practices more elaborately in the following chapters, but for our purpose here it is important to note that some of the sources hint at components of a pilgrimage culture that have also been signalled at other more officially sanctioned - places. ${ }^{82}$ Apart from praying, gazing at and sometimes even touching the stigmatics, there are also reports of the collection of relics. More specifically, visitors collected "contact relics" - relics which owed

Briefe offen und verschlossen, sowie auch Zettel, auf denen alles erdenkliche geschrieben steht," Staatsarchiv Amberg (StA), 4169 Bezirksamt Tirschenreuth, Schreiben der Gendarmeriestation Konnersreuth an das Bezirksamt Tirschenreuth, 57: 16/9/1927.

79 Scheer, "Das Medium," 172.

8o Davis and Boles, "Pilgrim apparition work," 376. For a similar use of small notes, see e.g. the present-day custom of leaving small notes on the grave of Anna Katharina Emmerick in the Heilig Kreuz Kirche in Dülmen.

81 Meyer, "Mediation," 29-30.

82 Journeys to stigmatics were also called pilgrimages. See e.g. "they made a pilgrimage to Kaldern" ("wallfahrteten nach Kaldern") (to Maria von Mörl), Görres, Die christliche Mystik, 5oo. See e.g. the case of Anna Maria Göbl: "I have been told that nowadays a glass with holy water and a palm branch is put on the table, with which they bless the patient who is laying on the bed, similar to how one blesses a dead person" ("Mir wird erzählt, dass man jetzt auf dem Tische ein Glas mit Weihwasser mit einem Palmsträuschen aufgestellt hat, womit die im Bett liegende Kranke gesegnet wird, ähnlich wie man einen Toten segnet.") ВАТ, BIII.12, 10 Bd.za, Causa Göbel-Faber, Bickendorf, Hauptakten I, April 1924-April 1927, Letter from Mayor Bickendorf to the Bishop, April 1927. 
their powers to the claim that they had been touched by divine personalities. ${ }^{83}$ Such relics could be almost any object, but particularly popular were pieces of cloth that had the blood of the stigmatics on them. By collecting these relics, the visitors demonstrate their trust in the special powers of the stigmatics. Furthermore, the "worship" of stigmatics was something that could also be cultivated at a distance. The letters of the devotees to the stigmatics asking for their prayers and those thanking them for their help, suggest that the devotees addressed these "living saints" as they would address any other divine person, and that the miracles attested to (e.g. cures) were "miracles at a distance." ${ }^{44}$

Saintliness was co-created in reports on the effectiveness of the stigmatic's prayers and relics through narratives about miraculous cures and conversion stories that circulated orally, but were also reported in periodicals such as the Konnersreuther Jahrbuch. ${ }^{85}$ However, we should be wary of adopting a solely instrumental approach (demand and answer), as the stigmatics also functioned as exemplars of Christian virtues. We find these hagiographic accounts in the summary biographies that were published during their lifetime and after their death. A closer look at the publications concerning two celebrity stigmatics, Louise Lateau and Therese Neumann, shows how their cases were regarded as exemplary for Catholic readers. The fact that these biographies were also published in Catholic book series shows that they had become household names and could function as religious models. Several of these books were published in series intended to improve the morality and knowledge of Catholic teachings of the audience (e.g. "La bonne lecture"/"Good literature", "Volksbibliotheek"/“People's library", "Geloofsonderricht"/"Religious education"). The stigmatic's virtuous life was presented as an example to the Catholic readers. This idealized interior life was something they could imitate - in contrast to the exterior aspects: the stigmata - and its presentation served the edification of the reader. ${ }^{86}$ The authors encouraged the readers

83 Bynum, "The sacrality," 10, n. 29, see also Walsham, "Introduction," 11, 14-15.

84 As different from miracles near the shrine, Signori, "Die Wunderheilung."

85 See e.g. "Eine Heilung," Konnersreuther Jahrbuch, 1932, 55.

86 In his biography of Louise Lateau (1874), for example, Henri Van Looy focuses on the interior aspect: "[...] that is the principal part that needs to serve for the edification of the fellow human, revitalize their faith and bring them to glorify the Lord [...]". (“[...] c'est là le côté principal, qui doit server d'édification au prochain, ranimer sa foi et le porter à glorifier le seigneur [...].") Van Looy, Biographie, 7. Or, on Therese Neumann: "Because this literature mostly has a beneficial effect on the reader and may thus be called an apostleship of the first category." ("Omdat zulke lektuur in de meeste gevallen heilwerkend inslaat bij den lezer, en daardoor een apostolaat mag geheeten worden van eerste gehalte.") Dewachter, Therese Neumann, 10. 
to go to Communion frequently, ${ }^{87}$ to learn about the power of suffering ${ }^{88}$ and find their way back to God. ${ }^{89}$

In addition, some authors published accounts of their personal visits to Louise Lateau and Therese Neumann. ${ }^{90}$ In doing so, they were the heirs of an older tradition, with Count Friedrich Leopold von Stolberg's narration of his visit (22 July 1813) to Anna Katharina Emmerick (1774-1824) having already been published several times in the early nineteenth century, ${ }^{91}$ while John Talbot, the Earl of Shrewsbury, also published an account of his visit to the Tyrolean stigmatics in $1841 .{ }^{92}$

When we look at the publications on visits to Therese Neumann at the start of the twentieth century, it becomes clear that these books had very diverse profiles. Some were self-reflective texts in which the author linked their own experience of visiting the stigmatic to broader reflections on society in general. ${ }^{93}$ Other books illustrate the dynamics that Suzanne Kaufman elaborately discusses in her study of the Lourdes pilgrimage site and Sofie Lachapelle in her work on the Assumptionists' Guide to Catholic France: the merging of consumerism and religious culture. ${ }^{94}$ These publications are best described as combinations of self-reflective texts and tourist guidebooks. L. Parcot, for example, included a map with travel information in his Ce que j'ai vu à Konnersreuth (What I saw in Konnersreuth, 1937), while A. Huybers, elaborated on which trains to take in his Naar en rond Konnersreuth. Persoonlijke indrukken en beschouwingen van onderweg en ter plaatse (To and around Konnersreuth:personal impressions and reflections on the road and on site, s.d.).

In addressing these unofficial cults - the ideas, practices and media used the majority of the following pages address focus on devotions that are outside the formal framework of the Catholic Church (i.e. not yet approved or disapproved).$^{95}$ We postulate that the faithful not only co-constructed the "saint" through religious practices and narratives about miraculous cures, but

\footnotetext{
87 Dewachter, Therese Neumann, 54.

88 Danemarie, Le mystère, 227.

89 On these books, see Van Osselaer, "Dor."

$90 \quad$ See e.g., Un pèlerinage à Bois-d'Haine (1871); Louise Lateau en 1877.

91 E.g. in the Hamburger Correspondent, but also in Theodor Lutterbekc's text, "Im Betreff der A.K. Emmerich" (1820). See "Zeitgenössische Resonanz", Stadtarchiv Dülmen (https:// www.duelmen.de/fileadmin/user_upload/duelmen.de/stadtarchiv/pr/ake/index.htm). Consulted on 5 July 2019.

92 On his letter and its effect in England, see Smeyers and Rossi, "Tyrolean stigmata."

93 E.g. the book by the Catholic convert Lars Eskeland, Mijn bezoek aan Theresia Neumann (My visit to Theresia Neumann) published in 1932.

94 See Kaufman, Consuming visions; Lachapelle, "Touring a once pious nation."

95 Margry, "New transnational religious cultures," 206.
} 
also the "stigmatic." Stories about celebrity stigmatics coloured expectations and influenced the narratives and depictions of new stigmatics (e.g. the visible bleeding wounds).

Studying our stigmatics as potential saints and celebrities at the same time allows us to aptly cover the changing media and devotional landscape of the nineteenth and early twentieth centuries. The enthusiasm for the modern stigmatics shows how older traditions lingered on (and were reinvented), but also how the new means (and their production scale) posed new challenges to the ecclesiastical authorities. While stigmata might have been reported since the thirteenth century, in the nineteenth and early twentieth centuries they made the headlines. 